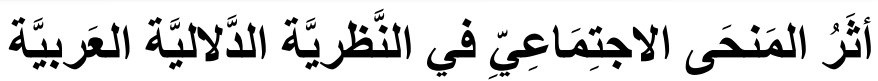

\author{
أ.م. د. لطيف عبد السادة سرحان \\ جامعة واسط /كلية التربية الأساسية/قسم اللغة العربية
}

lateefsharhan@uowasit.edu.iq

07711997050

$$
\text { تاريخ الاستلام : 25-201-021-06-04 :2021- تاريخ القبول }
$$

\title{
المستخلص
}

بحثُ في الجذور الاجتماعية التي يمكن رصدها في مباحث الدلاليين العرب القدامى بوصفها بعداً معرفياً يعتري بحث الظواهر الدلالية في إطار النظرية الدلالية العربية ؛ إذ يلاحظ أنّ عمل الدلاليين يقتفي منطلقين اجتماعيين رئيسين: الأول يتناول اللغة من حيث هي منجزٌ اجتماعيٌّ وليد العقد اللغوي الذي ينسالم عليه أبناء البيئة اللغوية الو اقع فيها تداول تلك اللغة وتعاطيها و الثاني يكتنفه الانتماء الاجتماعي في مفهومه القومي وما يستجليه من نوخي مبدأ المنطق الصوابي والنسبية الدلالية في الفصاحة بوصفها معيار اً لإتقان قو اعد اللغة و أنظمة الكلام و أحوال التعبير فيها ومن ثم يسلط الضوهُ على طبيعة معالجة القدماء في بحثهم للظواهر الدلالية وما بطرأ على ألفاظها من تطور بلحاظ الإطار الاجتماعي الذي تقع فيه حالات تلك الظواهر وبو اعث ذلك التطور.

الكلمات المفتاحية : النظرية الدلالية العربية، المنحى الاجتماعي ، بيئات الفصاحة، الظواهر الدلالية. 


\title{
The effect of social aspect in the Arabic semantic theory
}

\author{
Assistant Professor Dr. Lateef Abdulsada Sarhan \\ Wasit University / College of Basic Education \\ The department of Arabic language
}

Receipt date: 2021-01-25

Date of acceptance: 2021-06-04

\begin{abstract}
The research deals with the study of educational institutions that appeared in Aleppor which were established by Zengid and Ayyubid princes and sultans، in addition to statesmen and scholars and the role of these institutions in the development of the scientific life in Aleppo، which was mentioned in the book of Bughyat Attalab for Kamal Addin B. Al-'Adim. From mosques' mosques، and then schools، in addition to the khanqahs، zawiyas، and linkages in the Zangid era، then the Ayyubid.
\end{abstract}

Key words : Ibn Al-'Adim, Buġyat al-țalab, Educational institutions, Zengid, Ayyubid, Aleppo. 
المقدمة:

للمجتمع القول الفصل في تحديد ما يمكن أن يعتري لغته من تطور وتغير وتبدل ، فهي مظهر حركته العلمية ومرآة إبداعه الأدبي ووعاء نتاجه المعرفي ووسيلته إلى التواصل والتعبير ؛ لأنها واقعه المنطوق والحامل لكل أبعاده الفكرية. ومن هنا تأتي أهمية دراسة اللغة في حاضنتها الاجتماعية والوقوف على الأثر المترتب من الاجتماع الإنساني على اللغة ،وبيان عوائد اللغة على ذلك المجتم المستعمل لها ولاسيما في المستوى الدلالي ؛كون المعنى غاية المتكلم الأولى التي يمكن معها أن يسلك مختلف الطرق في سبيل الوصول إلى مبتغاه. فكان محط الكلام في ذلك عند النظرية الدلالية العربية وما رافقها من جهود كبيرة لعلماء اللغة القدامى، للوقوف على المفاصل المهمة منها وبيان أثر الأبعاد الاجتماعية فيها، للإطلال من خلال ذلك على البواكير الأولى للحركة الدلالية وامتزاجها بالبعد الاجتماعي وإسهام ذلك في بناء علم الدلالة العربي، والوقوف على الموضوعات الدلالية التي تتاولها القدماء في إطرها الاجتماعية كالبحث في نشأة اللغة وما يلازمه من القول بالدلالة الوضعية، ومباحثات النسبية الدلالية في الفصاحة وما يتصل بها من توزيع المادة اللغوية على البيئات الفصيحة وما أثار ذلك من مباحث الغرابة اللغوية ،وصولاً إلى أثر المواضعات الاجتماعية في الظواهر الدلالية كالترادف والاشتراك والتضاد . جذور الاتجاه الاجتماعي في العربية .

الانسان اجتماعي بالطبع ولتميزه بهذه الصفة كانت لغته منجزاً لاجتماعيته الجانحة بالفطرة إلى التواصل وضرورة

التفاهم بين بني جنسه ، ولا غرو إن وجدنا هذا البعد الاجتماعي متحققاً بين سائر المخلوقات ، فللكثير منها نوع لغةٍ ما يتقاهم بها أفراده ، وبوجود الاجتماع ولوازمه لابدَّ للفرد من اللغة من حيث هي ((أصوات يعبر بها كل قوم عن أغراضهم))(ابن جني ،د.ت،ج1،ص33) • وعند إنعام النظر في الواقع اللغوي عامة والدلالي خاصة تتضح جذور البعد الاجتماعي ممتدة في البحث الدلالي العربي ، ويتجلى ذلك في بواكيره الأولى التي يمكن تلمس أسسها في المحاولات اللغوية الدلالية المتقدمة إبان صدر

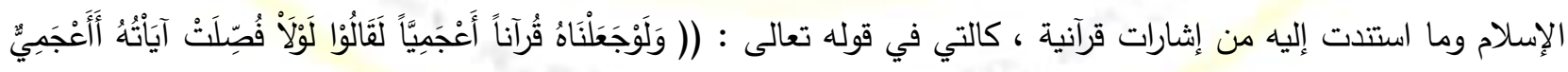

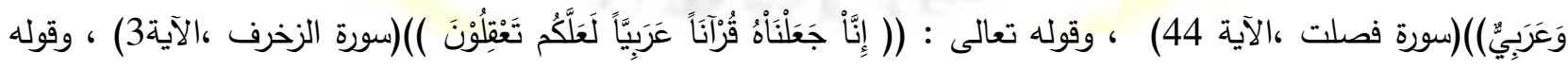

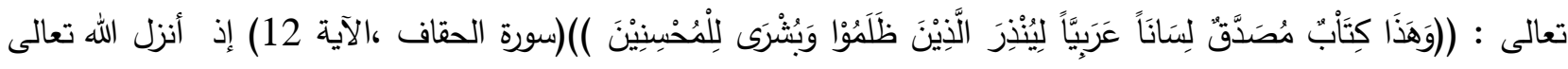
كتابه الكريم بأفصح لغات العرب وأعربها وأبينها وسار على سمتها وراعى استعمالاتها(الأنباري ،2007،ص24،ابن 
فارس،2005،ص47 وما بعدها،الطبرسي،2005،ج9،ص29، 67 ،142، الفيروزآبادي،2002،ص481، 489 ،504) وفي هذا إشراك للمجتمع العربي بوصف العربية وعاء المحتوى القرآني إلى جانب مشاركة القرآن الكريم ذلك المجتمع باستعمال لغته والتواصل مع أفكاره وثقافته ، ولهذا اكتسبت الفصاحة أهمية كبيرة في التداول الاجتماعي ويتضح ذلك فيما يروى عن النبي

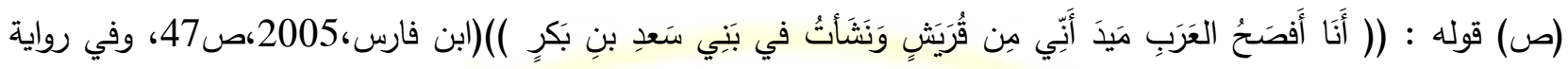
أخرى(بيد) بدلاً من (ميد) ،السيوطي،1998،ج1،ص167) وبناء على أهمية الانتماء الاجتماعي وأثره في التحكم بمستوى الفصاحة ،وما يرتبط من ذلك بالقيم البيئية ومدى تدخلها في بلورة الكفاية اللغوية لاى الناطقين يظهر البعد الاجتماعي معياراً في (الواقع المعرفي ، وقد نجد صدى هذا عند الخليفة عمر بن الخطاب حين سمع رجلاً يقول : (عتَّى) وهو يقرأ قوله تعالى : (2) لَيَنْجُنُنَّهُ حَتَّى حِيْنِ)(سورة يوسف، الآية35) فقال: (( من قرأ هذا ؟ قال : ابن مسعود ... ثم كتب إلى ابن مسعود : سلام عليك ، أما بعدُ فإنَّ الله أنزل القرآنَ فجعله قُرآناً عربياً مبيناً ، وأَنزله بلغة هذا الحَي من قُريش ، فإذا أتاك كتابي هذا فأَقرئ الناسَ بلغة قريش ولا تُقرئهُم بلغة هُذيل )(الأنباري،2007،ص25). وبهذا سلك معيار الفصاحة سلوكاً اجتماعياً صارماً ،متحولاً من إطاره اللغوي إلى الإطار التداولي الكلامي ومن الموطن الواسع للعقد اللغوي إلى أفق البيئة اللهجية القبلية ، وعلى هذا ازدادت معيارية المنطق الصوابي من جهة ، وحددت مناشئ ذلك المنطق وملاكاته بتوخي اللهجة الموحدة من جهة أخرى ـ ولعل من الطبيعي في المجتمع المسلم أن يكون الوازع الديني هو الواقف وراء توخي المعيارية اللغوية في التعبير والتواصل الاجتماعي، ولا سيما في تعاطي أقس نص كالمدونة القرآنية ـ وفي خضم هذا الجو الذي يمثل طرفَه الأول الدينُ الإسلامي وتمثل طرفَه الثاني القوميةُ العربيةُ، تولد ثنائية متحدة مؤلفة من( لغة الدين ودين اللغة) وبهذا يقف الدين عاملاً فاعلاً - إلى جانب القومية العربية- في توخي الصواب اللغوي (الفصاحة) ومن ثم تصبح اللغة الوسيلة الضرورية لفهم الدين إلى جانب تعبيرها عن الانتماء القومي . ونظراً إلى أنَّ الدين هو مقوم المجتمع المعرفي واللغة مقومه التواصلي فقد ألفا معاً إيديولوجية اجتماعية تقضي باستهجان الخروج على المنطق الصوابي ومعيارية النسبية الدلالية في الفصاحة ، ومن هنا عُدَّ الخروج على المتداوَل اللغوي اجتزاءً للمضامين القرآنية التي استوعبها نظام العربية في مستواه اللهجي الذي مثلته الرواية السابقة بلغة (قريش) ـ وبهدي من هذا الواقع الداعم للفصاحة والرافض للحن؛ لما للأمرين من تأثير اجتماعي مباشر على الواقع المعاش سلباً وإيجاباً، يفهم الاهتمام الذي أولاه الإمام علي (ع) بهذا الصدد حين أشار على أبي الأسود الدؤلي (68هـ) بوضع النحو وذلك في صحيفته التي ضمنها أسساً نحوية عامة ثم دفعها إلى أبي الأسود وكلفه بالزيادة عليها ، وما ذاك إلا بغية الحفاظ على قيمة التواصل اللغوي في إطاره الاجتماعي 
والتتويه على أهمية التعبير عن المراد على وفق نظام اللغة الأصيل ، وهذا ما يفهم من فحوى الحوار الذي جرى بينهما إذ يقول أبو الأسود : (( دخلت على علي بن أبي طالب رضي الله عنه فرأيته مطرقاً متفكراً ، فقلت : فيَم تفكر ياأمير المؤمنين ؟ قال: إني سمعت ببلدكم هذا لحناً فأردت أن أضع كتاباً في أصول العربية فقلت : إن فعلت هذا أحييتا وبقيت فينا هذه اللغة ()(الزجاجي،1987،ص238) ، إذ لو سمح بتفي اللحن لتصدع بضرره الواقع الاجتماعي ؛كون اللغة منتجاً إنسانياً لايُستعمل إلا في إطاره الاجتماعي على وفق نظام تواصلي تعبيري ، ووجود المخالفة اللغوية ( اللحن) يعني انقطاع سلسلة ذلك التواصل ونظام ذلك التعبير ومن ثم سيثهد المجتمع مشكلة لغوية تواصلية لاسبيل إلى حلها .ولعل هذا عينه ما يفسر لنا التأكيد على التداول اللغوي للمفردات التي سأل عنها نافعُ بن الأزرق ابنَ عباس (رض) (69هـ) في مسائله المشهورة تلك التي راهقت المئتين ، إذ كان يسأل عن دلالة اللفظ القرآني وابن عباس يفسر لله معناه ثم يعقب ويردف سائلاً عن مدى معرفة العرب بهذا التفسير

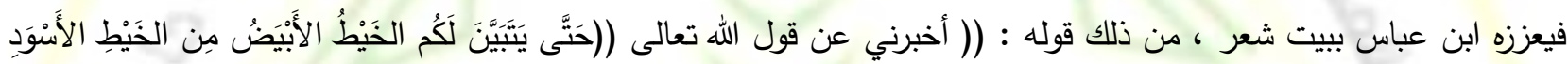

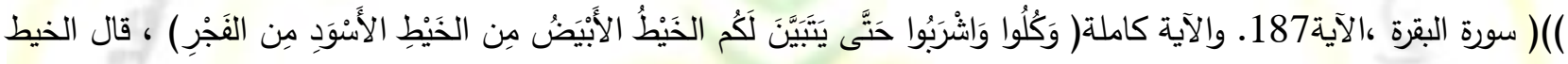
الأبيض ضوء النهار والخيط الأسود سواد الليل ، قال : فهل كانت العرب تعرف ذلك قبل أن ينزل القرآن ؟ قال: نعم ، قال أمية بن أبي الصلت :

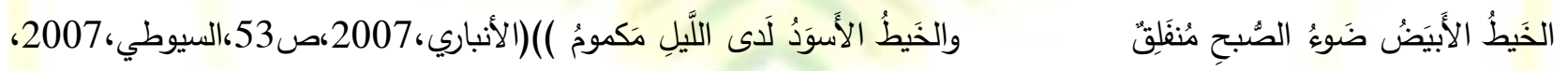
$\cdot(200-183$ - 180 إنَّ هذه المباحثة الدلالية كان هدفها المعرفة القرآنية والتثبت من الحكم المترتب عليها بيد أن المعيار المتَّع في استقصائها اجتماعي تداولي ، انطلاقاً من كون مغردات اللغة منجزاً دلالياً للناطقين بها ؛ ولهذا أكد ابن الأزرق على ضرورة أن يكون التتسير مما عرفته العرب قبل نزول القرآن كي يصلح أن يُحتَّى عليه ، فملاك الفصيح والصحيح اللغوي هو النتاج الأصيل للتعاقد الاجتماعي والتداول الجمعي • وتأسيساً على هذا يمكن تفسير حجم الاستهجان الذي يُرمى به من يلحن بكلامه آنذاك () (لفي ظل التأكيد الكبير على نبذ ذلك السلوك المتكب للفصاحة ومعالجته بتعلم العربية والنطق على سمتها من قبيل قولهم :

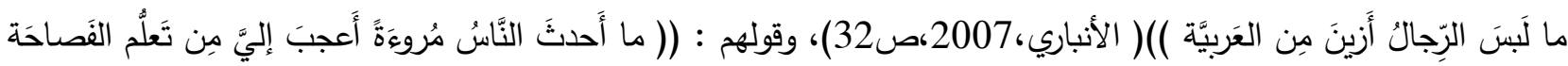

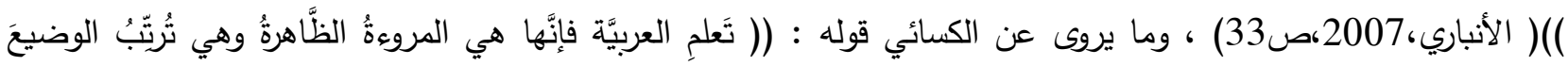




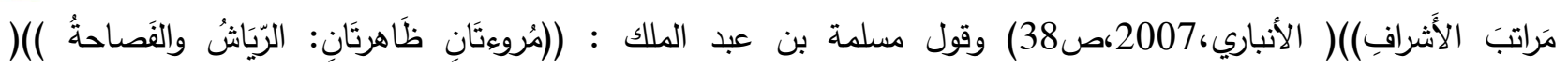
الأنباري،2007،29 ) وقول عبد الملك بن مروان لغلامه حين استأذنه رجل من علية أهل الثام وكان بين يديه قوم يلعبون بالشطرج : (( يا غلامُ غَطِّها ، فلما دخل الرجل فتكلم لحن ، فقال عبد الملك : يا غلامُ اكثِفت عنها الغطاءَ لَيسَ لِلََحنٍ حُرمةٌ )(الأنباري،1932،154) • إلى غير ذلك من الروايات الكثيرة الدالة على نبذ اللحن واستقباحه ومفارقة مرتكبه صفاتِ المروءة والكمال (الزبيدي ،د.ت،ص11-13،الأنباري،1932،ص150 -155،الأنباري،2007،ص26 - 44)وكأن ذلك - أعني اللحنَ- فقدان جزء من الشخصية الاجتماعية العربية ، فمن لم يكن فصيحاً فهو مطعون بعربيته وانتمائه لتلك البيئة . وبلحاظ هذا الاهتمام الكبير بتعلم العربية والحرص على اتقان فصاحتها تظهر للرائي معالم البيئة اللغوية التي برع فيها علماء العربية الأوائل ، أولئك الذين وطدوا الأمر في البحث والدراسة والتقصي ولاسيما في مستواها الدلالي ، وكانوا منطلقين فيما يبحثون من خضٍَّ هذه البيئة المحافظة وهذا التوجه المفعم بالأصالة ، الذي يرى أن تحقق الكفاية اللغوية شرط اجتماعي ضروري في كل ناطق بالعربية .ولبيان مضامين المنحى الاجتماعي في المنجز الدلالي العربي لابد من الوقوف على مفاصل مهمة في ذلك يمكن اجمالها في ثلاثة مطالب : الأول صلة البعد الاجتماعي بمباحثات نشأة اللغة الإنسانية وما يتبعها من القول بنوع الدلالة فيها ، والثاني تدخل الاتجاه الاجتماعي بطبيعة التوزيع البيئي للمادة اللغوية الفصيحة ، والثالث أثر المواضعات الاجتماعية في الظواهر الدلالية نشأة وبحثاً. التعاقد الاجتماعي والدلالة الوضعية . تقع مباحثات نثأة اللغة في طليعة الجهود الدلالية العربية ذات الصبغة الاجتماعية ؛كونها تأسيساً دلالياً من حيث تسلسلها بين موضوعات علم الدلالة بوصفها منشأ دلالياً للغة ـ فمعلوم أنَّ الباحثين قديماً وحديثاً مختلفون في أمر النشأة اللغوية ولم تتفق كلمتهم على تقسير معين، ومن بين تلك التفسيرات القول بأن أصل اللغة إنَّما هو تواضع واصطلاح واتفاق بين مجموعة الناطقين بتلك اللغة على وفق عقد لغوي مبرم بينهم مجتمعين، وعلى هذا الرأي جمع من علماء العربية ( ابن جعفر، د.ت، ص69، الفارابي ،2004، ص134-144، ابن جني د.ت ، ج1، ص44، المعتزلي ،د.ت،ج5، ص172، مسكويه، 2001، ص43-36، ابن سينا،1970،العبارة3، ابن سيدة ،د.ت ،ج1، ص302، الخفاجي، 2010، ص72، الجرجاني ،1992، ص49، الغزالي،1993 ، ص193) ،ونظراً إلى ضيق المقام بذكر آرائهم ومناقشتها جميعاً سنذكر المهم منها على وفق تعاطيها 
(المنحى الاجتماعي الذي يعتري تفسيرات النشأة وما يترتب على ذلك من القول بالدلالة الوضعية، إذ يقول الفارابي(339هـ) () إنَّ الألفاظ تُشرعها الأمم وتضعها كما تشرع الثرائع في الأفعال وغيرها ، وواضعو الألفاظ هم أيضا واضعو الثرائع في الأفعال ربما كانت باصطلاح جماعة من جمهور أو مدينة ، أو بأن تشرعها لهم جماعة مدبرون لهم،أو يشرعها لهم مدبر واحد يحملهم ،كذلك الألفاظ وكذلك الخطوط)) (الفارابي،1960،العبارة27). فالجهد الجمعي حاضر بقوة في تفكير الفارابي وهو يفسر أوليات المنشأ اللغوي ، فلابد عنده أن يكون منطلق اللغة الأول من واقع المجتمع حتى وإن كان المبتدع فرداً مدبراً؛ لأنَّ الملاك في اللغة استعمالها وتداولها الجمعي ولولا تداول الجماعة الناطقة اللغةَ لم يعد ذلك الابتداع لغة، مادامت حبيسة ذلك الفرد ولم تر بعد نور التواطؤ والتعاقد والاتفاق الاجتماعي أو تترسخ بالتداول وتكتسب ملكة التعبير وتحقق غاية التواصل • ويوافق ابنُ جني(392هـ) الفارابيَّ في أنَّ اللغة تواضع واصطلاح وذلك (( كأن يجتمع حكيمان أو ثلاثة فصاعداً فيحتاجون إلى الإبانة عن الأشياء المعلومات ،فيضعوا لكل واحد منها سمة ولفظة إذا ذكر عُرف به مُسمَّاه ليمتاز من غيره؛ ليغني بذكره عن إحضاره إلى مرآة العين )(ابن جني، د.ت، ج1،ص44) وعلى الرغم من الانتقادات العلمية والمؤاخذات التي توجه إلى هذا التقسير و في مقدمتها غياب لغة العقد الاجتماعي وسبل التفاهم على وضع تلك اللغة(عبد التواب،1997،ص111-112) ،إلا أنَّ المهم هو أن التقسير واقع في ظل البعد الاجتماعي وآخذ بضرورة أن تولد اللغة الإنسانية من رحم التجمعات البشرية، التي تؤلف علة ابتداع اللغة لما تتطوي عليه من حاجة فطرية للتواصل فكانت اللغة سبيله إلى ذلك . وإلى جانب هذا يرى ابن جني أنَّ ظاهرة تعدد اللغات وانشعابها منبثقة من المبنى الاجتماعي أيضاً إذ يمكن (( أن تتقل هذه المواضعة إلى غيرها فتقول : الذي اسمه إنسان فليُجعل مكانه مَرْد والذي اسمه رأس فليُجعل مكانه سَزْ ، وعلى هذا بقية الكلام))((ابن جني،د.ت،ج1،ص44) .ويتقق ابن سينا (421هـ) مع سابقَيه باجتماعية اللغة وأنَّها (( إنَّما تدل بالتواطؤ ، أعني أنَّهَ ليس يلزم أحداً من الناس أن يجعل لفظاً من الألفاظ موقوفاً على معنى من المعاني ولا طبيعة الناس تحملهم عليه ، بل قد واطأ تاليهم أوَّلَهم على ذلك وسالمه )(ابن سينا،1970،العبارة3) ، استتاداً إلى أنَّ اللغة منظومة إثارية ولا بد في اتحاد جزأي كل إثارة فيها من تدخل التواطؤ والاتفاق المبرم بين ناطقيها لخلق الترابط الإشاري بين الدال والمدلول ، فالواقع هو الذي ينتج المدلول عليه ويبقى الدال من مهمة اللغة؛ لذا يتذخل الوضع والاتفاق الجمعي في منحه بعداً آيقونياً في التداول • ويشِّه الجرجاني (471هـ) أصل الوضع اللغوي بإطلاق التسمية على الأشخاص من حيث التوافق الاجتماعي وأثره في تأليف الدلالة إذ (( إنَّ الرجل يواضع قومَه في اسم ابنه ، فإذا سمَّاه زيداً فحاله الآن كحال واضع اللغة حين جعله مصدراً لزاد يزيد )(الجرجاني،1991،ص325) .فالمواضعة القومية 
(الاجتماعية) في تفكير الجرجاني هي ملاك الدلالة اللغوية . وعند التأمل في مقالات الدلاليين آنفة الذكر يتضح البعد الاجتماعي في منطق مقاصدهم ، فاللغة عندهم منجز اجتماعي لا ينعقد أمره إلا بالتدخل الجمعي والمشاركة العامة لأفراد البيئة اللغوية ؛ لأنَّ الغرض من وضع اللغة هو التواصل والتعبير بين أفراد البيئة الواحدة وعلى هذا فمسؤولية إيجاد عنصر التفاهم تقع على عاتق الجميع ، وهي بعد - أعني اللغة- أداة يفرزها الاجتماع وتفرضها حركة المجتمع ويتدخل في إيجادها أبناء ذلك • الوسط

التوزيع البيئي للغة الفصحى •

أولاً : بيئات الوضوح الدلالي .

نحا علماء العربية منحى اجتماعياً أيضاً في استقراء المادة اللغوية الفصيحة من مجتمع الناطقين بالعربية من

ذوي الكفاية اللغوية ، إذ انتخبوا مجموعة من البيئات اللغوية على وفق ضوابط ابتدعوها يقع في مقدمتها ضابطا الزمان والمكان كما سيأتي بيان ذلك ـ إنَّ اختيار الفصاحة قضيةً دلاليةً في إطارها الاجتماعي آت من كونها نسبيةً دلاليةً في تحديد وضوح المعنى وغموضه على وفق الخصائص الأصيلة للغة وقواعد نطقها وأحوال الكلام فيها ـ فما كان من المادة اللغوية مراعيً فيه هذه الخصائص والأحوال فهو فصيح، وتحدد درجة فصاحته على وفق استيفائه شروطَ الفصاحة المعهودة في تلك البيئة ـ أما ما اشتُهر من كون الفصاحة مبحثاً بلاغياً متعلقاً باللفظ دون المعنى فهو لا يخلو من أحد أمرين : الأول أن يراد به الوضوح والإبانة عن المعنى وهذا الأمر - بلا شك- شأن دلالي وإن وقع في مباحث البلاغة. الثاني أن يراد به مجرد اللفظ دون المعنى ، فإن كان المقصود به اللفظ المفرد فهذا قول بالفصل بين جزأي الدلالة اللغوية وهو ما لا يقره علم اللغة ، وإن أريد به النص ( الوحدة الدلالية النصية ) فهو مشتمل على المعنى بوصفه جزءاً من الدلالة اللغوية ؛ لأنَّ اللفظ صوت ومعنى أي : معنىً منطوق ، وإذا كان كذلك فهو أمر عائد للدلالة لاشتماله على المعنى • وبهدي مما سبق يمكن القول إنَّ الفصاحة مطلب دلالي محض ، وما دار فيه من خلاف وكلام بين الدلاليين لا يخلو مما مرت مناقتته .وعند النظر في مباحث الفصاحة الدلالية لدى القدماء وما يتعلق بذلك من توزيع اللهجات والقبائل وعلاقة البعد الزمني ومراعاة الاحتكاك اللغوي والموقع الجغرافي وطبيعة التكوين الديموغرافي ، تظهر معالجتهم الموضوعَ على وفق المواضعات الاجتماعية وما لذلك من صلة بالحيشيات المكملة للبعد الاجتماعي ومرتبطة عضوياً به كالقومية والعرق والعقيدة ـ وعلى الرغم من أنَّ كل هذه الحيثيات تذوب في النهاية بالبوتقة 
الاجتماعية ويظل العنصر المهيمن في الأمر هو المنجز اللغوي في إطاره المجتمي ،بيد أنَّهم عالجوا هذه القضية معالجات مختلفة بحسب الثقافة والمعرفة التي يتمتع بها اللغوي ، فمنهم من تتاولها بوصفها ضابطاً نحوياً وآخر بحثها في موضوعات البلاغة وثالث درسها في فنون الأدب وما إلى ذلك ،وقد تعددت مشارب القوم فيما عالجوا ،ويمكن تقسيم ذلك على ثلاثة أقسام رئيسة هي :

الأول : المشترك اللغوي الفصيح .

ويرى أصاحبه أن معيار القول بفصاحة أي استعمال لغوي إنَّما هو لغة قريش ؛ كونها اللغة الفصحى المشتركة بين اللهجات وتقاس فصاحة الاستعمال على وفق قربه منها ومراعاته لمتداولها ، وهذا ما يراه الفراء (207هـ) بقوله : (( كانت العرب تحضر الموسم في كل عام وتحج البيت في الجاهلية وقريش يسمعون لغات العرب ، فما استحسنوا تكلموا به فصاروا أفصح العرب وخلت لغتهم من مستبشع اللغات ومستقبح الألفاظ )((السيوطي،1998،ج1،ص175). وعلى هذا فهو يرى أنَّ الإتقان اللغوي والكفاية اللغوية إنَّما تتحصلان بالاكتساب والمعايشة والاقتراض ، بفعل الاحتكاك الاجتماعي باللهجات الوافدة ومن ثم تكون هناك فصاحة ملفقة من عدة فصاحات . وعلى الرغم من قول المبرد (285هـ) باصطلاحية اللغة وتواضعها في وسطها الاجتماعي وأنَّ فصاحتها تقاس بما تحققه من بيان وتفاهم وتواصل بين ناطقيها ،إلاًّ أنَّه يعتقد بأن معيار المفاضلة من ناحية الفصاحة بين اللهجات هو محاكاة لغة قريش إلى جانب القرآن الكريم إذ يقول : (( كل عربي لم تتغير لغته فهو فصيح على مذهب قومه ، وإنَّما يقال بنو فلان أفصح من بني فلان أي : أشبه لغةً بلغة القرآن ولغة قريش )((المبرد،1956،ص113) •ولهذا يرى ابن خالويه (370هـ) (( إن سأل سائل فقال : أوفى بعهده أفصح اللغات وأكثرها فِلمَ زعمت ذلك ؟ وإنَّما النحوي الذي ينقِّر عن كلام العرب ويحتج عنها ويبين عما أودع الله تعالى ذكره من هذه اللغة الثريفة هذا القبيل من الناس وهم قريش)(الدرويش،1990،ص290) •وإلى هذا يذهب ابن فارس (395هـ) بقوله : (( إنَّ قريشاً أفصح العرب ألسنةً وأصفاهم لغةً )(ابن فارس،2005،ص41) ، ويحذو حذو الفراء في تعليل فصاحة قريش بقوله : (( كانت قريش - مع فصاحتها وحسن لغتها ورقة ألسنتها - إذا اتتهم الوفود من العرب تخيروا من كلامهم وأشعارهم أحسن لغاتهم وأصفى كلامهم ، فاجتمع ما تخيروا من تللك اللغات إلى نحائزهم وسلائقهم التي طبعوا عليها فصاروا بذلك أفصح العرب))( ابن فارس،2005،ص41)وعلى الرغم من أنَّ القول بالفصاحة المطلقة للهجة قريش أمر فيه نظر والمقام لايسمح بمناقشته ؛ إذا علمنا أنَّ القرآن نزل بكل لغات العرب 
الفصيحة ولم تكن لقريش غلبة في ذلك على سائر اللغات ، فضلاً عن كونها واحدة من بين مجموعة اللهجات التي انتخبها النحاة في أخذ المادة اللغوية ، إلا أنَّ المهم في ذلك إثارة أصحاب هذا الاتجاه إلى أنَّ لغة قريش هي القدر اللغوي المشترك بين العرب أسهم في تلفيقه وتأليفه أمران أحدهما الوضع الأول وما درجوا عليه من التداول والثاني الاكتساب اللغوي بفعل الاحتكاك باللغة الوافدة ، إذ ألقت الحياة الاجتماعية لقري وما تحمله من تعدد طبقي وثقافي بظلالها على الواقع اللغوي ،فأوجد هذا الحراك الاجتماعي لغة وسطى يمكن للجميع استعمالها بيسر ووضوح • الثاني : التباين البيئي. ويرى دعاة هذا الاتجاه أنَّ الذي يحدد الفصاحة هو تباين الواقع المعاش لمجتمع أهل اللغة وما يتصل بذلك من درجة الرقي والثقافة ؛ نظراً إلى تأثيره المباشر في نوع المتداول اللغوي وتحكمه بإقرار دلالاته في التعامل اليومي لذلك المجتمع .إذ يرى ابن طباطبا العلوي (322هـ) أنَّ : (( الثاعر إذا أسس شعره على أن يأتي بالكلام البدوي الفصيح لم يخلط به الحضري المولَّد ()(العلوي،2005،ص12) فالبداوة شرط في تحقق الفصاحة والأخيرة صفة ملازمة للبداوة ، وما ذاك إلا لأنَّ البدوي محافظ قليل اللقاء بالغرباء والوافدين ،الذين باحتكاكهم تتد منهم استعمالات لغوية قد تؤثر بالموروث البدوي ،على أنً في الأخير مناعة منيعة من التأثر بالوافد بلحاظ الطبيعة الاجتماعية والبيئية التي يعيشها ، مما يتطلب لغة وتداولاً يلائمان واقعه ويحسنان التعبير عنه كما يريد وهو ما قد لايؤديه الوافد اللغوي من الحاضرة ـ ويظهر هذا الفهم واضحاً عند الفارابي إذ يقول : (والفصيح منها من سكان البراري من هم دون أهل الحضر ، ثم من سكان البراري من كان في أوسط بلادهم ومن هم أشد توحشاً وجفاءً وأبعدهم إذعاناً وانقياداً ، وهم قيس وتميم وأسد وطي ثم هذيل ، فإنَّ هؤلاء معظم من نقل عنه لسان العرب )((الفارابي،2004،ص147)،ولعل هذه النظرة البيئية الصارمة هي التي دفعت الهذذاني (244هـ) إلى انتقاء البيئات الفصيحة حين يرى أنَّ الفصاحة في العَروض باستثناء قراها ، والأمر نفسه في بيئات الحجاز ونجد السفلى والثام وديار مضر وربيعة فكلها فصيحة ما عدا قراها (الهذاني،1974،ص178-279). وفي ضوء هذا فإنَّ الفصاحة تتناسب عكسياً مع الاختلاط وكثرة الاحتكالك بالبيئات الأخرى مما يسلم إلى التأثر بالوافد ويورث لينَ اللسان ويعلل ابن جني ذلك في باب( ترك الأخذ عن أهل المدر كما أُخذ عن أهل الوبر ) إذ يقول : (( علة امتتاع ذلك ما عرض للغات الحاضرة وأهل المدر من الاختلال والفساد والخطل، ولو علم أنَّ أهل المدينة يلقون على فصاحتهم ولم يعترض شيء من الفساد للغتهم لوجب الأخذ عنهم كما يؤخذ من أهل 
الوبر ، وكذلك أيضاً لو فثا في الوبر ما شاع في لغة أهل المدر من اضطراب الألسنة وخبالها وانتقاض عادة الفصاحة وانتثارها لوجب رفض لغتها وترك ما يرد عنها ))(ابن جني،د.ت،ج2،5) وعلى الرغم من أن ابن جني يعلل تحديد الفصاحة على وفق درجة نقاء اللغة من الوافد غير الفصيح سواء أكان ذلك في المجتمع البدوي أم في نظيره الحضري ،إلا أنَّ مناط الفصاحة يبقى مرتبطاً بالبيئة البدوية بوصفه أصلاً من أصول القول بالسلامة اللغوية؛ لما تتماز به هذه البيئة من نقاء لغوي بحكم ابتعادها عن الاختلاط المؤثر في السليقة ونأيها عن الاحتكاك الاجتماعي بالحواضر ، وما هذا الانغلاق إلا لخصوصية الحياة البدوية وطبيعة العيش فيها مما لايترك مندوحة لمد أواصر التواصل مع الآخر بمستوى أكبر من المتاح • الثالث : التداول الثقافي · يميل أهل هذا الاتجاه إلى القول بأنَّ البيئة الفصيحة هي تلك التي يؤدى فيها المعنى أداءً واضحاً مبيناً وهي بيئة الفصحاء والعلماء ،وفي هذا يقول الجاحظ : (( وأنا أقول إنَّه ليس في الأرض كلام هو أمتع ولا آنق ولا ألذّ في الأسماع ولا أشدُ اتصالاً بالعقول السليمة ولا أفتق للسان ولا أجود تقويماً للبيان ،من طول استماع حديث الأعراب العقلاء الفصحاء والعلماء البلغاء وقد أصاب القوم في عامة ما وصفوا )(الجاحظ،د.ت،ج1،ص145) ، وإلى هذا يذهب ابن وهب الكاتب (400هـ) إذ يرى أنَّ (( أفصح الكلام ما أفصح عن معانيه ولم يحوج السامع إلى تفسير له بعد أن لايكون كلاماً ساقطاً ولا للفظ العامة مشبهاً )(الكاتب،1967،ص206) ولعل صفة الاعتدال اللغوي التي ينشدها ابن وهب وقبله الجاحظ تتوافر في أثناء طبقة المتثقين وطلاب المعرفة وأهل الخطابة والبيان والتأليف ومن هو في ركابهم ،ومؤونته في ذلك المشهور من المتداول العربي الفصيح ومن هنا فإنَّ (( الفصيح من الكلام ما وافق لغة العرب ولم يخرج عما عليه أهل الأدب، ولتصحيح ذلك وضع النحو ولجمعه وضعت الكتب في اللغة ... وحق من ينشأ في العرب أن يستعمل الاقتداء بلغتهم ولا يخرج عن جملة ألفاظهم ولا يقنع من نفسه بمخالفتهم فيخطِّيُوه ويلحِنوه ()(الكاتب، 1967،ص252) م ثانياً : بيئات الغموض الدلالي · n مثلما أفرز البحث في الفصاحة مجموعة من الاتجاهات والمعايير الاجتماعية التي نتج منها القول بوجود اللغة الفصيحة من عدمها ،كذلك الحال في شأن ما قد يعتري الألفاظ من غموض في دلالاتها نتيجة لما يرافق تداولها من حيثيات اجتماعية وما 
يحيط بها من ظروف ،فضلاً عما تفضي إليه معايير الفصاحة من استهجان لما عدَّ خارجاً على ضوابط الاستعمال الفصيح ولبيان ذلك تقسم هذه البيئات على ثلاثة أقسام هي :

1

لم يكتف القدماء بوضع محدداتهم الزمانية والمكانية التي فرضوها على مستقرئ اللغة والمستثه بفصيحها بل توسدوا

المبدأ الاجتماعي في التمييز بين اللهجات المستوفية لشروطه في الاحتجاج وسواها المخالفة لتلك الشروط ، وفي هذا يقول ثعلب (291هـ) : ((ارتفعت قريش في الفصاحة عن عنعنة تميم وكثكثة ربعة وكسكسة هوازن ))(ثعلب،2006،ج1،ص2081،وتتمة النص هي : (وتضجع قيس وعجرفية ضبة وتلتلة بهراء ...)،ابن جني،د.ت،ج2،ص11) .وهذا المترفع عنه ما يعرف ب) اللغات المذمومة ) التي خالفت الفصاحة - برأيهم- من جهة وترفعت عنها لهجة قريش التي تمثل الذروة في الفصاحة عندهم - من جهة أخرى ، وهو إن كان واصماً شيئًا فإنَّما يصم المجتمعات الناطقة بتلك اللهجات، بوصف اللغة انعكاساً لثقافة مجتمعها فالملاك في كلا الجانبين ( قري وهذه اللهجات) هو المجتمع · ويشارك ابن فارس ثعلباً في هذا النحو إذ يقول في حديثه عن قريش : ((ألا ترى أنك لاتجد في كلامهم عنعنة تميم ولا عجرفية قيس ولا كثكثة أسد ولا كسكسة ربيعة ))(ابن فارس،2005،ص41) ، والحق أنَّ جعل هذا الاستعمالات اللهجية لغات مذمومة أو مستهجنة أو مستقبحة إنَّما هو رأي اللغويين لا الناطقين من بقية أبناء العربية ، إذ لم نجد - في حدود الاطلاع- من يستقبح هذه اللغات أو يعيب قبائلها على تداولها ، ولعل نزوع دعاة المشترك اللغوي الفصيح نحو تفضيل لهجة قريش هو الذي أدى إلى القول باستهجان هذه الاستعمالات وعد لغاتها دون مرتبة قريش في الفصاحة كونها مستعملة فيها . يضاف إلى هذا كله أنَّ لهجة قريش ليست كما وصفها أنصارها بأنها اللغة المشتركة ومنحوها السيادة على سائر القبائل وفضلوها بخلوها من مما نعتوه بـ( اللغات المذمومة أو مستبشع اللغات ومستقبح الألفاظ)(ابن فارس،2005، ص22،السيوطي،1998،ج1،ص175) ولعل ما يؤيد هذا قول الفارابي : (( والذين عنهم نقلت العربية وبهم اقتذي وعنهم أخذ اللسان العربي من بين قبائل العرب هم : قيس وتميم وأسد فأنَّ هؤلاء هم الذين عنهم أكثر ما أخذ ومعظمه، وعليهم اتكل في الغريب وفي الإعراب والتصريف ثم هذيل وبعض كنانة وبعض الطائيين ولم يؤخذ عن غيرهم من سائر قبائلهم ))( السيوطي،1998،ج1،ص167) نعم يرى أنَّ قريشاً كانت ((أجود العرب انتقاداً للأفصح من الألفاظ وأسهلها على اللسان عند النطق وأحسنها مسموعاً وأبينها عما في النفس )(( السيوطي،1998،ج1،167)غير أنَّ هذه 
الصفات لا ترقى بها إلى ما وضعها فيها دعاتها من الكمال والرفعة بل نزهوها عما رأوه مستقبحاً في غيرها من اللغات ـ والذي يبدو أنَّ ارتياح اللغويين للغة قريش لما وجدوه فيها من الاستعمالات المتفشية والتداول السهل وما يحيط بذلك من أبعاد عقدية واجتماعية هو ما دفعهم إلى تفضيلها واستهجان سواها ، وقد يصح ما ذهبوا إليه لو أنهم جعلوا معيار الفصاحة ما رأوه فيها لا ما اعتمد فيه عنصر البداوة والخلوص من الاختلاط بلغة الحضر وما إلى ذلك كما مر .على أنَّ الأمر لم يكن بمنأيً عن العامل السياسي القائم على حيثيات الواقع الاجتماعي بتفصيلاته العرقية والدينية والقبلية وغيرها ، إذ يروي لنا الجاحظ ما قد يكون أساس القول بالتفضيل والاستهجان إذ يقول : (( وقال معاوية يوماً : من أفصح الناس ؟ فقال قائل قوم ارتفعوا عن لُخلخانية الفرات وتيامنوا عن عنعنة تميم وتياسروا عن كسكسة بكر ليست لهم غمغمة قضاعة ولا طمطمانية حمير ، قال : من هم ؟ قال : قري . قال ممن أنت ؟ قال : من جرم ، قال اجلس )(الجاحظ،د.ت،ج3،ص212-213) ومهما يكن من أمر فإنَّ أصحاب هذا المذهب يرون أنَّ المذموم اللغوي فيه مفارقة للفصاحة والمشترك التداولي وينبغي أن يترفع عنه المستوى اللهجي ليرقى إلى ذروة الفصاحة . - 2

ومما دعا إليه اقتفاء المنحى الاجتماعي في دراسة اللغة هو ما يعرف بالغريب اللغوي المرتكز على مخرجات الفصاحة ومعاييرها التداولية ، فما عرف في بيئات الفصاحة فهو متوافر على شروط النسبية الدلالية وما لم يعرف عُدّ غربباً؛ كونه فاقداً صفة التفشي الفصيح الواضح • وقد يكن القول بغرابة الكلام يستلزم النسبية فضلاً عن نسبية الفصاحة نفسها ،فما عدَّ غريباً في بيئة ما فهو فصيح متفش في بيئته إذ هو غريب خارج بيئته فصيح فيها ، وعلى هذا فمعيار المجتمع المعهود هو المائز الحقيقي في ذلك .فانتماء المستعمل اللغوي إلى بيئة البداة الأقحاح يعني استغلاق معناه واستكراه استعماله وكأنَّهَ لايعبِّر إلا عن بيئته ومتطلباتها النائية ؛ لذا يرى قدامة بن جعفر (337هـ) أنَّ استحسان الكلام الغريب فيما لو استعمل (( ليس من أجل أنه حسن لكن من شعرائهم من كان أعرابياً قد غلبت عليه العَجرفة ومسَّت الحاجة إلى الاستشهاد بأشعارهم في الغريب )((ابن جعفر،د.ت،ص172)ويؤكد الخطابي (388هـ) أنَّ البيئة البدوية الموغلة بالنأي والعزلة هي المنتجة للغريب إذ يقول :( فليست الغرابة بما اشترطناه في حدود البلاغة وإنَّما يكثر وحثي الغريب في كلام الأوحاش من الناس والأجلاف من جفاة العرب الذين يذهبون مذاهب العُنجُهيَّة ولا يعرفون تقطيع الكلام وتتزيله والتخيَّر له )(الرماني والخطابي والجرجاني،د.ت، ص33-34). إذن 
فالمجتمعات البدوية الأعرابية التي تقطن الأماكن النائية والتفار الموحشة هي التي تتداول ذلك الغريب اللغوي الذي استهجنه الدلاليون العرب وعدوه مستويًٌ فضَّاً من اللغة لايلجأ إليه إلا الفضُ المتوحش من الناطقين • وهو المراد من قول الخطابي حين قََّم الغريب بقوله : (( إنَّ الغريب من الكلام يقال على وجهين : أحدهما يراد به بعيد المعنى غامضه ولايتتاوله الفهم إلا عن بعد معاناة فكر ، والوجه الآخر أن يراد به كلام من بعدت به الدار ونأى به المحل من شواذ القبائل ، فإذا وقعت إلينا الكلمة من لغاتهم استغربناها وإنَّما هي كلام القوم وبيانهم )(الخطابي،1982،ج1،ص171). ورُبَمَا وقف الغريب اللغوي معادلاً موضوعياً للبيئة المنتجة له في خلد بعض اللغويين كابن رشيق القيرواني (456هـ) حين يرى أنَّ اللفظة إذا كانت (( خشنة مستغربة ، لايعلمها العالم المبرز أو الأعرابي القح )(القيرواني،2007،ج2،ص269) وكلمة (كهل) عند ابن سنان الخفاجي (466هـ) () لفظة ليست بقبيحة التأليف لكنها غرببة لايعرفها مثل الأصمعي)(الخفاجي،2010،ص88) م ـوفي ضوء هذا كله كان المعيار في التداول والاستعمال الاجتماعي للغة هو المحدد لدلالة الكلمة عند عبد القاهر الجرجاني إذ يقول: (( هل يقع في وهم وإن جها أن تتفاضل المفردتان .. بأكثر من أن تكون هذه مألوفة مستعملة وتلك غريبة وحشية )(الجرجاني،1992،ص44). وفي ضوء ما مر فإنَّ عزو اللفظ إلى الغرابة مبعثه غرابة البيئة الاجتماعية التي وضع فيها ذلك اللفظ وشاع فيها ذلك الاستعمال ، وكما قال أحدهم حين أنثد قوماً شعراً فاستغربوه : ليس هذا بالغريب ولكنكم في الأدب غرباء(الزمخشري،2001،ص534)، وهذا الاستغراب يتتاسب طردياً مع الواقع المعاش فكلما بعدت البيئة عن الاختلاط والاحتكاك كلما زادت منجزَها اللغوي غرابةً وغموضاً في البيئات اللغوية الأخرى . 3 - الوحثي اللغوي.

يأتي مصطلح الوحشي أو الحوشي من الألفاظ نعتاً ثالثاً لدى القدماء عند بحثهم النسبية الدلالية وبيئات الغموض الدلالي فيها ، وقد ارتبطت دلالة المصطلحين بذلك النوع من الألفاظ غير المألوفة في المتداول اللغوي المشترك ، وهما إنَّما حازا هذا التوصيف بفعل النأي المكاني والاعتزال الاجتماعي والبعد عن التعامل اللغوي المشترك ،مثلهما مثل النوعين السابقين كما مر . والمستعمل لهما هو المجتمع البدوي أيضاً نظراً إلى احتفاظ هذا النوع من المجتمعات بمعم ثَّر من الألفاظ والاستعمالات والأساليب والأحوال اللغوية، المتفقة ونمط العيش والتخاطب ومستويات الوعي والثقافة لدي سكانه، في وقت يجهل دلالاتها الكثير من الناطقين بالعربية بلحاظ ما ذكر • وقد تتاول القدماء هذا الموضوع إلى جانب المذموم اللغوي والغرابة اللغوية ؛كون 
هذه المفاهيم تؤلف لديهم خروجاً على ضوابط النسبية الدلالية في الفصاحة ومخالفة بيانية لسمات التوصيل والتعبير في اللغة ؛ ومن ثَّ طال الغريبَ اللغويَّ من الثجب والرفض ما نال سابقَيهِ من قبل ـ لذا عدَّ الجاحظ هذا النوع من الاستعمال لغة البيئة المتوحشة وهو ما يناسب طبائع أهلها في التعامل إذ يقول : (( إلاَّ أن يكون المتكلم بدويَّاً أعرابياً فإنَّ الوحشي من الكلام يفههه الوحشي من الناس ... وكلام الناس في طبقات كما أنَّ الناس في أنفسهم في طبقات)(الجاحظ،د.ت،ج1،ص144). والذي يبدو أنَّ مشكلة الوحشي لم تكن في أصل دلالته ووضعه وما يمكن أن يعتريه من الغموض والتعمية والاستغلاق ،إذا افترضنا ولادة اللفظ في ظروف استثنائية يعتريها الثك أو الخطأ أو التوهم ، بل هي مشكلة توصيلية تعبيرية بين طرفي الرسالة ( المرسل والمرسل إليه) ، وما ذاك إلا لانقطاع الصلة بين وضع اللفظة وتداولها في بيئتها الأولى وبين متلقيها الجديد ؛ لذا ألزم ابن طباطبا العلوي الثاعر في أسلوبه أَنْ (( إذا سهَّل ألفاظه لم يخلط بها الألفاظ الوحشية النافرة الصعبة القيادة )(العلوي،2005،ص12) ، بل يراه قدامة بن جعفر محذوراً لغوياً ينبغي اجتنابه فهو عنده : (( ما ليس يستعمل ولا يتكلم به إلا شذوذاً وذلك الحوشي )((ابن جعر،د.ت،ص172) ، فإذا ورد استعماله لايقاس عليه في التداول ؛ لأنَّ الأسلوب السوي المعتدل هو ما اجتبب الحوشي مثلما يرى القاضي الجرجاني ( 366هـ) إذ يقول :(( النمط الأوسط ما ارتفع عن الساقط السوقي وانحط عن البدوي الوحشي ))(الجرجاني،2006،ص30) م ـ وعلى الرغم من فحوى مقولات القدماء في الوحشي والحوشي الدالة على رفضهم الغموض الدلالي الذي يكتنفه ،غير أنَّهم لم يصدروا من ملاك لغوي محض في ذلك الرفض، فهذه مشكلة قد يتكفل الاستعمال والتداول بحلها تدريجاً ،بل لديهج - فيما يبدو - نزوع جامح لاستيحاش البداوة وعاداتها وحيثياتها التي من جملتها تلك الاستعمالات اللغوية ، فكان نعت الألفاظ بهذه النعوت - في أكبر الظن- نتيجة منظور معرفي ذي صبغة طبقية تدور حيثياته بين دارسي العربية ومستعمليها في حاضنتها البدوية ـ ولايبعد أن يتأثر الدلاليون بمنطلقات اجتماعية متأثرة بالموروث القبلي ونظرة الاستغراب للبيئة البدوية، فضلاً عما يفهم من منطلقات دينية أشار القرآن الكريم إلى بعضها (كقوله تعالى : ( الأَعْرابُ

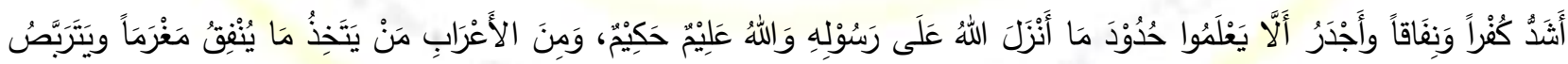

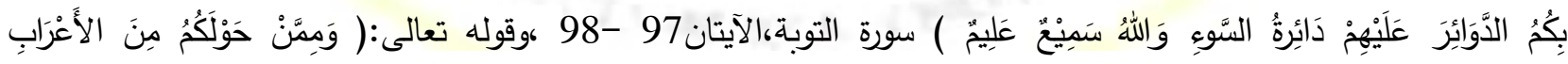

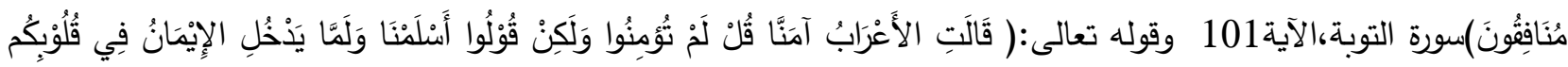
)الحجرات/14 وينظر :سورة التوبة،الآية 120 ،سورةالفتح ،الآيتان 11 ،16 ). 
• ويبدو أنَّ في إطلاق مصطلح الوحشي أو الحوشي تتكباً للواقع اللغوي ؛ إذ لا ينبغي نعت ما لا تعرف دلالته من الألفاظ بالتوحش والتوعر وردف ذلك ، إذا علمنا أنَّ تلك المستعمَلات ليست غريبة بين ناطقيها بل هي نماذج فصيحة عندهم إن لم تكن فصحى ، ولو صح معيار الدلاليين في رفضها لوجب نعت كل لغات الأرض بذلك ،بلحاظ وحدة ملاك الرفض فحكم الأمثال فيما يجوز ولا يجوز واحد كما يقال . وكان بمقدور القدماء إطلاق الوحشي والحوشي على اللغات غير العربية كالفارسية والهندية وسواها ، لكنهم لم يفعلوا بل نعتوها بالأعجمية لانتفاء الدلالة فيها أولاً ولعدم تعاطيهم إياها على وفق المواريث الاجتماعية ثانياً وهذا ما يؤيد ما ذكرنا آنفاً . الظواهر الدلالية .

من الأجزاء المهمة في النظرية الدلالية العربية التي بحثها القدامى في أطرها الاجتماعية تلكم الظواهر الدلالية وما قد يعتريها من تطور دلالي ، وينتظم معالجات الدلاليين منحيان رئيسان أحدهما يرتبط بالأسباب والعوامل الاجتماعية الواقفة وراء نشوء الظواهر الدلالية ، والآخر يهتم بالسبل الاجتماعية المتحكمة بتطور الدلالة اللفظية لتلك الظواهر .ويمكن إجمال جهودهم في دراسة هذا المستوى من اللغة في بعدين رئيسين : الأول : التباين اللهجي .

يحظى اختلاف اللهجات بحضور وافر في حل إثكالات اللغة وأحوالها المختلفة ، نظراً إلى تمثيله الصلة العملية بين المبدع الناطق باللغة والمادة الإبداعية وما تتطوي عليه من محتوى الرسالة اللغوية من ناحية والمتلقي وما يحيطه من ملابسات الموقف اللغوي من ناحية أخرى • إذ يكمن في التعدد اللهجي بيان إرهاصات النشوء الدلالي في المنجز اللغوي وهذا ما يلحظ في الظاهرات الدلالية كالترادف والاشتراك اللفظي والتضاد وأثباهها ـ وقد توخى الدلاليون هذا المفهوم عند دراستهم المعنى وراعوا فيه حيثياته الاجتماعية التي يمكنها الاشتراك والتدخل في تأليف النص وبيان معناه من ذلك مثلاً ما يراه ابن السراج (316هـ) في تقسير الاشتراك اللفظي إذ يقول : (( وهذا ادعاء من ادعى أنَّه ليس في لغة العرب لفظتان متفتان في الحروف إلا لمعنى واحد، لكنه أغفل أنَّ الحي أو القبيلة ربَّما انفرد القوم منهم بلغة ليس سائر العرب عليها ، فيوافق اللفظ في لغة قوم وهم يريدون معنى لفظ آخر من لغة آخرين وهم يريدون معنى آخر، ثم ربما اختلطت اللغات فاستعمل هؤلاء لغة هؤلاء وهؤلاء لغة هؤلاء )((ابن السراج،1973،ص33) • فالاحتكالك اللغوي أساسه الاختلاط المجتمعي بين الناطقين وكل ذلك يؤلف العلة وراء نشأة 
المشترك اللفظي في الاستعمال المشترك ـ. وحين يصل الكلام على التضاد الذي هو جزء من الاشتراك يُحكِمٍ ابن الأنباري (328هـ) التباينَ اللهجي وخلفياته الاجتماعية بذلك ليقول : (( إذا وقع الحرف على معنيين متضادين فمحال أن يكون العربي أوقعه عليها بمساواة منه بينهما ، ولكن أحد المعنيين لحي من العرب والمعنى الآخر لحي غيره ، ثم سمع بعضهم لغة بعض فأخذ هؤلاء عن هؤلاء وهؤلاء عن هؤلاء، فالجون الأبيض في لغة حي من العرب والجون الأسود لغة حي آخر ثم أخذ أحد الفريقين من الآخر )(الأنباري،2011،ص18) .ونجد المعالجة السوسيولوجية عند ابن درستويه (343هـ) في تحليل خلفيات ظاهرة الترادف إذ يقول : (( لايكون فَعل وأفعل بمعنى واحد كما لم يكونا على بناء واحد ،إلا أن يجيء ذلك في لغتين مختلفتين فأما من لغة واحدة فمحال أن يختلف اللفظان والمعنى واحد ... وليس يجيء شيء من هذا الباب إلا على لغتين متباينتين كما بينا أو يكون على معنيين مختلفين أو تشبيه شيء بشيء )((ابن درستويه،1975،ج1،ص165166،السيوطي،1998،ج1،303) ويتابعه ابن جني في ذلك بقوله : (( وإذا كثر على المعنى الواحد ألفاظ مختلفة فسمعت في لغة إنسان واحد ،فإنَّ أحرى ذلك أن يكون قد أفاد أكثرها أو طرفاً منها من حيث كانت القبيلة الواحدة لا تتواطأ في المعنى الواحد على ذلك كله )(ابن جني،د.ت،ج1،ص373) فالترادف إذن جها جمعي مؤلف من عدة أجزاء كل واحد منها يمثل لفظاً منتمياً إلى مجتمع معين من الناطقين في بيئة مختلفة ، وبهذا فمفهوم الاجتماع هو المتحكم في النشأة في حال التعدد والوضع ، وهو المتحكم أيضاً في حال التوحد والتداول إذ (( كلما كثرت الألفاظ على المعنى الواحد كان ذلك أولى بأن تكون لغات لجماعات اجتمعت لإنسان واحد من هنا وهناك))((ابن جنيد.ت،ج1، ،374) • وفي ضوء مامر تتضح أهمية البعد الاجتماعي وأثره في الكثف عن أوليات الظواهر اللغوية ولاسيما الدلالية منها ؛ إذ صدر الدلاليون آنفاً في آرائهم عن منحى اجتماعي أثبتوا تحكُمه المؤثر في نشوء الظواهر الدلالية على ألسنة الناطقين . فالنواميس الاجتماعية بوصفها منظومة من التفكير الفردي المتوافق ،في ظل عقد اجتماعي أسهمت في إبرامه بينهم الذات الإنسانية المشتركة وما يمكن أن يلحق بها من مواضعات وتقاليد وعادات ومشتركات بيئية وثقافية ومعرفية ،لا تسمح بوجود وضع لغوي مزدوج نظراً إلى انتفاء الحاجة الإنسانية والاجتماعية لمثل هذه المواضعات ،فضلاً عن المانع العقلي في جانب الحسن والقبح العقليين من توخي دالين والتواضع عليهما معاً لددلول واحد كما في الترادف ،أو التواضع على دال واحد لمدلولين مختلفين كما في المشترك ، فهو إن لم يكن محالاً عقلاً فهو محال عقلائياً. ولهذا سبر القدماء غور هذه الأبعاد الاجتماعية ووققوا على جزئياتها، ومن ثم دلهم ذلك على توظيفها والاتتفاع بها في الرفض والتأييد والتحليل والتقسير للظواهر الدلالية . 
مثلما كان للحراك الاجتماعي أثر في الدرس الدلالي العربي كان للقيم والعادات والتقاليد السائدة في المجتمع أثر في ذلك أيضاً ، إذ وققت بعض الأعراف عاملاً مساعداً على نثأة بعض الظواهر الدلالية مقتفية في الأغلب أثر المعنى الكنائي ، وقد رصد الدلاليون القدامى هذه الآليات الاجتماعية مؤكدين على مساهتها في مسار الدلالة اللغوية وتطورها ويمكن إجمال هذه الأبعاد على النحو الآتي : 1

يمكن أن يكون لتجنب الخوض في المعاني التي تخدش الحياء أثر في أن يكنى حياءً عما هو مستقبح ذكره منها ومثال ذلك : (( أنّهم كنُوا عن الفرج فقالوا : كثف لنا متاعه فصار المتاع والفرج سواء ، والفرج والقبل والدبر كله أيضاً كنايات )((الجاحظ،1982،ص106) ، ومنه أيضاً تسميتهم ((رجيع الإنسان الغائط وإنَّما الغيطان البطون التي كانوا ينحدرون فيها إذا أرادوا قضاء الحاجة )((الجاحظ،2003،ج1،،216) • · 2

معلوم أن ظاهرة التشاؤم سمة لايكاد يخلو منها تجمع إنساني كونها صفة تعتري طبع الإنسان ، وهي هنا تقف عاملاً خلف بعض الظواهر الدلالية كالترادف والتضاد ومثالها في تسمية العرب الغراب بالأعور إذ : (( علموا أنَّه نافذ البصر صافي العين ... فسموه الأعور كنايةً ))(الجاحظ،1982،ج1،ص387) فلو أريد به الغراب كان ترادفاً ولو أريد به صفاء العين كان تضاداً . 3

وهي من الأساليب الاجتماعية ذات تأثير في السلوك الإنساني ولها دخل في التطور الدلالي للألفاظ إذ (( قد يستعمل الناس الكناية ، وربَّما وضعوا الكلمة بدل الكلمة يريدون أن يظهر المعنى بألين اللفظ إما تتويهاً وإما تفضيلاً كما سموا المعزول عن ولايته والمنهزم عن عدوه منحازاً ، نعم حتى سمَّى بعضهم البخيل مقتصداً ومصلحاً وسُمِّي عامل الخراج المتعدي بحق السلطان مستقصياً))(الجاحظ،د.ت،ج3،ص140) • وبهذا قد أسهمت بنشأة الترادف في اللغة . 
هناك ما يسوء الإنسانَ أن يعتريه أو يسمعه أو يراه وما إلى ذلك من العيوب الخلقية أو حوادث الأمور ؛ ونتيجة لذلك يتطير منها فيأتي بلفظ مضاد لها تفاؤلاً ، من ذلك مثلاً أنَّ العرب ((كنَّوا طيرةً عن الأعمى فكنَّوه أبا بصير ... ولذلك سمُوا الملدوغ والمنهوش سليماً وقالوا للمهالك من الفيافي المفاوز وهذا كثير )(الجاحظ،1982،ج1،ص1387) . وهذا النوع من المواضعات كما هو واضح يسهم في إيجاد الأضداد في اللغة . · 5

للسخرية والاستهزاء والتهكم نصيب في اصطلاحات الظواهر الدلالية كالمشترك اللفظي مثال ذلك إطلاق لفظة العاقل على الجاهل إذ (( مما يشبه الأضداد أيضاً قولهم للعاقل ياعاقل وللجاهل إذا استهزأوا به يا عاقل))(الأنباري، 2011،ص161) ، ومنه أيضاً إطلاق لفظ القشيب على الثوب الخلق تهكماً واستهزاءً (اللغوي،1996،ص186،عبد التواب،1980،ص1350) . · 6

ومن المؤثرات الاجتماعية في المستوى الدلالي ظاهرة توقي الحسد والعين ومثاله (( أن يُسَّى الجميل شيطاناً على جهة التطيُر له كما تسمى الفرس الكريمة شوهاء والمرأة الجميلة صماء وقرناء وخنساء وجرباء وأشباه ذلك )(الجاحظ،1982،ج1،433) ، ومن ذلك أيضاً إطلاق الأعور على الحديد البصر وتسمية المرأة العاقلة بالبلهاء والسيف الصقيل بالخشيب (قطرب،1932،ص1256،الأنباري،2011،ص203،اللغوي،1996،ص175) . خاتمة ونتائج

عقب هذه الإطلالة على ما عنَّ للبحث من موضوعات البعد الاجتماعي في مباني الدلالة العربية آن لهذه الدراسة أن تسجل أهم ملاحظاتها لتؤلف نتائج البحث وهي كالآتي :

1 - صدر اللغويون من منطلقات اجتماعية في معالجاتهم الدلالية ،لها جذور قد تغذيها الأبعاد العقدية والقبلية والعرقية . 2 - رصد القدامى حالة الارتباط الوثقى بين عادات الناطقين ولغتهح سواء أكان على مستوى الفرد أم المجتمع ومن ثم بينوا آثار ذلك الارتباط على المعنى المتداول . 
3 - استتد اللغويون كثيراً إلى البعد البيئي وبنوا عليه أحكاماً قد تفتقر إلى الدقة في بعض الأحيان كما الحال في الفصاحة

وتوزيعها الديموغرافي • n

4 - أوضح القدماء في مباحثهم أن اللغة ممارسة حيوية يقوم بها الفرد والمجتمع إلى جانب بقية الممارسات الإنسانية الأخرى التي لابد أن تتأثر بها اللغة في إطارها الاجتماعي ·

5 - رفض الدلاليون العرب أن تولد اللغة من غير رحم التعاقد الاجتماعي كي يمكنها احتمال أفكار المجتمع الناطق بها ، فضلاً عن كونها انعكاساً طبيعياً لمزاج المجتمع ونواميسه وأنظمته فهي المجتمع ناطقاً وهو اللغة صامتة . 6 - مثلت مباحث القدماء تسويغاً وتعليلاً للمنز اللغوي عامة والدلالي خاصة، حين بينوا الأبعاد الاجتماعية المتحكمة في ذلك المنجز ووضحوا أثرها فيه ،ومن هنا أكدوا أنَّ حركة المجتمع هي صاحبة القول الفصل في كلِّ ما يعتري اللغة من تبدل أو محافظة .

7 - كان هدف اللغويين من اقتفاء أثر البعد الاجتماعي الحفاظ على أصالة العربية وصونها من التحريف والارتقاء بنصوصها الإبداعية إلى المستويات اللغوية الرفيعة التي نزل بها القرآن الكريم وتكلم بها الفصحاء . والحمد لله أولاً وآخراً

· المصادر والمراجع القرآن الكريم

[1] ابن خالويه وجهوده في اللغة مع تحقيق كتابه شرح مقصورة ابن دريد، دراسة وتحقيق: د. محمد جاسم الدرويش، دار الثؤون

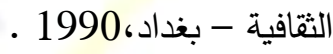

[2] الإتقان في علوم القرآن ،جلال الدين السيوطي، ضبطه وصحَّحه وخرَّج آياته: محمد سالم هاشم،22،دار الكتب العلميةبيروت،2007 . [3] أساس البلاغة ، جار الله الزمخشري، ط1،دار إحياء التراث العربي-بيروت،2001. [4] أسرار البلاغة ،عبد القاهر الجرجاني ،قرأه وعلَّق عليه: محمود محمد شاكر،1،مطبعة المدني - القاهرة،1991. 
[5] الاشتقاق ،أبو بكر بن السراج ،تحقيق: محمد صالح التكريتي ، بغداد ،1973م •

[6][الأضداد في كلام العرب، أبو الطِّب اللغوي، تحقيق: د. عزَّة حسنط2،دار طلاس - دمشق،1996. [7] [ الأضداد ، قُطرُب ،نشر كوفلر ،مجلة إسلاميكا ،1932م.

[8] الأضداد، محمد بن القاسم الأنباري، تحقيق: محمد أبو الفضل إبراهيم، المكتبة العصرية- بيروت،2011. [9] أمالي الزجاجي، أبو القاسم الزجاجي، تحقيق: عبد السلام هارون ،2،دار الجيل-بيروت،1987.

[10] إيضاح الوقف والابتداء في كتاب الله عزو جل، أبو بكر ابن القاسم الأنباري ،تحقيق : الثيخ عبد الرحيم الطرهوني ، دار الحديث- القاهرة ،2007 م

[11] البرصان والعرجان والعميان والحولان، عمرو بن بحر الجاحظ، تحقيق: عبد السلام محمد هارون، دار الرشيد-الجمهورية العراقية، 1982.

[12] البرهان في وجوه البيان ،ابن وهب الكاتب ،تحقيق :د .أحمد مطلوب ود. خديجة الحديثي،1،هطبعة العانيبغداد،1967. [13] البيان والتبيين، عمرو بن بحر الجاحظ، تحقيق: عبد السلام محمد هارون، دار الفكر، د.ت . [14] تصحيح الفصيح ، ابن درستويه ،تح: عبد الله الجبوري ، بغداد 1975 ـ [15] تتوير المقباس في تفسير ابن عباس، مجد الدين الفيروزآبادي،1،دار إحياء التراث العربي- بيروت،2002. [16] ثلاث رسائل في إعجاز القرآن للرماني والخطابي والجرجاني، تحقيق: محمد خلف الله ومحد زغلول سلام، دار المعارفمصر ، د.ت . [17] الحروف ،أبو نصر الفارابي، تحقيق: محسن مهدي،33،دار الشروق - بيروت،2004. [18] الحيوان، عمرو بن بحر الجاحظ، تحقيق: إبراهيم شمس الدين ،ط1،مؤسسة الأعلمي- بيروت،2003. [19] الخصائص ،أبو الفتح عثمان بن جني، تحقيق: محمد علي النجار،ط2،دار الهدى-بيروت ،د.ت . [20] دلائل الإعجاز ،عبد القاهر الجرجاني، قراهه وعلَّق عليه :محمود محمد شاكر،ط3،مطبعة المدني- القاهرة،1992. [21] رسائل الجاحظ، عمرو بن بحر الجاحظ، تحقيق: عبد السلام محمد هارون، مكتبة الخانجي- القاهرة، د.ت . [22] سر الفصاحة ،ابن سنان الخفاجي ،قدَّم له واعتنى به ووضع حواشيه: إبراهيم شمس الدين،ط1،بيروت،2010. 
[23 شرح الفارابي لكتاب أرسطو طاليس في العبارة ، عني بنشره :ولهم كوتش اليسوعي وستانلي مارو اليسوعي ، المطبعة الكاثوليكية- بيروت،1960.

[24] الثفاء - المنطق - العبارة، ابن سينا، تحقيق :د. محمود الخضري ،دار الكتاب العربي- القاهرة،1970. [25] الصاحبي كتاب في فقه اللغة ،أحمد بن فارس، تحقيق: السيد أحمد صقر ،ط1،مؤسة المختار - القاهرة،2005. [26] صفة جزيرة العرب، الحسن بن أحمد الهمداني، تحقيق: م حمد بن علي الأكوع، دار اليمامة - الرياض،1974. [27] طبقات النحويين واللغويين ،أبو بكر الزبيدي ، تحقيق: محمد أبو الفضل إبراهيم ،ط2،دار المعارف - مصر ، د.ت. [28] العمدة في محاسن الثعر وآدابه ونقده، الحسن بن رشيق القيرواني، تحقيق :د. عبد الحميد هنداوي، المكتبة العصريةبيروت،2007.

[29] عيار الثعر ،ابن طباطبا العلوي ، تحقيق: عباس عبد الساتر،22،دار الكتب العلمية- بيروت،2005. [30] غريب الحديث، حمد بن محمد الخطابي، تحقيق: عبد الكريم العزباوي، جامعة أم القرى،1982. [31] الفاضل ،محمد بن يزيد المبرد، تحقيق: عبد العزيز الميمني ،دار الكتب المصرية- القاهرة،1956. [32] فصول في فقه العربية، د. رمضان عبد التواب،ط2، مكتبة الخانجي- القاهرة1980. [33] مجالس ثعلب ،أحمد بن يحيى ثعلب، شرح وتحقيق: عبد السلام محمد هارون،6،دار المعارف- القاهرة2006. [34] مجمع البيان في تفسير القرآن ،أبو علي الطبرسي، تحقيق: لجنة من العلماءط2،مؤسسة الأعلمي للمطبوعاتبيروت،2005. [35] المخصص، ابن سيدة، دار الكتب العلمية- بيروت، د.ت . [36] المدخل إلى علم اللغة ومناهج البحث اللغوي، د. رمضان عبد التواب،3،مكتبة الخانجي - القاهرة،1997. [37] المزهر في علوم اللغة وأنواعها، جلال الدين السيوطي، ضبطه وصححه ووضع حواشيه :فؤاد علي منصور ،ط1،دار الكتب

$$
\text { العلمية- بيروت،1998. }
$$

[38] معيار العلم في فن المنطق، أبو حامد الغزالي، قدم لله وعلق عليه وشرحه: د. علي بو ملحمط1،دار الهلالبيروت،1993. 
[39] المغني في أبواب التوحيد والعدل، القاضي عبد الجبار،ج5،الفرق غير الإسلامية، تحقيق: محمود محمد الخضري، الدار

$$
\begin{aligned}
& \text { المصرية للتأليف والترجمة، د.ت . } \\
& \text { [40] نقد الشعر ،قدامة بن جعفر، تحقيق: محمد عبد المنعم خفاجي، دار الكتب العلمية-بيروت، د.ت . } \\
& \text { [41] الهوامل والثوامل، أبو علي مسكويه، تحقيق: سيد كسروي،1،دار الكتب العلمية- بيروت، 2001. }
\end{aligned}
$$

\section{Sources and Reference:}

The Holy Quran

[1] Ibn khaliwih and efforts in language with the investigation of his book( sharah maqsurat Ibn

Duraid ) study and investigation by: Dr.muhammad jasim Al-Darwish, Cultural Affairs House Baghdad,1990 .

[2] (Al-etkan) in the sciences of Qur'an ,jalalulddin al-Sioty,seized and corrected and eliminated verses: Muhammad Salem Hashem, 2st,Dar al-kutub al-Eilmeea, Beirut,2007 .

[3] Asas al-balagha, Jar Allah Al-zamakhshary, 1st,Dar Ihya Al-turath Al-Arabi- Beirut,2001.

[4] Asrar Al-Balagha, Abdul-Qahir al-Jurjani ,read and commented on by :Mahmoud Muhammad Shakir, 1st, Edition Almadani - Cairo,1991.

[5] The Derivation ,Abu bakr Ibn Al-Sarraj, investigation: Muhammad Salih Al-Tikrity , Baghdad , 1973 .

[6] The Opposites in the speech of Arab, Abu Al-tayeeb Al-lughwy, investigation:Dr.ezzat Hassan, 2 st,Dar Telas - Damascus, 1996.

[7] The Opposites,Qutrub ,spread of coveller,Journal of Islamika ,1932.

[8] The Opposites,Muhammad Ibn Al-Qasim Al-Anbary, investigation : muhammad Abu Al-fadl Ibrahim,Al-maktaba Al-asreea- Beirut,2011.

[9] Amali Al-Zajjajy,Abu Al-Qasim Al-Zajjajy, investigation: Abd Al-Salam Haroon , 2st,Dar AlJeel- Beirut, 1987. 
[10] Clarification of Endowment and commencement in the Book of God Cherished and Exalted, Abu Bakr Ibn Al-Qasim Al-Anbari, investigation : The Religious Abd Al-Rahim Al-Tarhuni , Dar Al-Hadeeth- Cairo,2007 .

[11] The Lepers and The Lames and The Blinds and The Squints,Amr Ibn Bahr Al-Jahiz, investigation: Abd Al-Salam Muhammad Harun,Dar Al-rashid-The Republic of Iraq,1982.

[12] Al-Burhan in the Faces of The Statement , Ibn Wahab Al-Katib, investigation:Dr .Ahmed Matlob and Dr.Khadija Al-Hadithi, 1st, Edition Al-Ani- Baghdad,1967.

[13] The Statement and The Showing ,Amr Ibn Bahr Al-Jahiz, investigation:Abd Al-Salam Muhammad Harun, Dar Fluent Al-Fikr,w.d.

[14] The Eloquent Correction, Ibn Durstowih, investigation :Abdullah Al-Juburi , Baghdad 1975 .

[15] Tanweer Al- Meqbas in the Explanation of Ibn Abaas,Mujd Al-Diyn Al-Fairuzabady, 1st,Dar ihya Al-Turath Al-Arabi- Beirut,2002.

[16] Three Letters in The miraculous of Qur'an ,Al-Rummany and Al- Khattaby and Al-Jurjany, investigation:Muhammad Khalaf Allah and Muhammad Zaghlul sallam,Dar Al-Marf- Egypt,w.d

[17] Al-huroof ,Abu Nasr Al-Faraby, investigation:Muhsin Mahdi, 3st,Dar Al-ShrwqBeirut, 2004.

[18] The Animal ,Amr Ibn Bahr Al-Jahiz, investigation: Ibrahim Shams Al-Diyn , 1st, corporation of Al-Aalami- Beirut,2003.

[19] The Properties ,Abu Al-Fath othman Ibn Jenni, investigation: Muhammad Ali Al-Najjar, 2st,Dar Al-Huda- Beirut,w.d.

[20] The Guides of The Miraculous ,Abd Al-Qahir Al-Jurjany,Read it and commented on it:Mahmood Muhammad Shakir, 3st, Edition Almadani - Cairo,1992. 
[21] Letters Al-Jahiz,Amr Ibn Bahr Al-Jahiz, investigation: Abd Al-Salam Muhammad Harun,Library Al-Khanjy -Cairo,w.d .

[22] Secret Eloquence, Ibn sinan Al-Khafaji ,submit to him and take care of it and put its margins: Ibrahim Shams Al-Diyn, 1st, Beirut,2010.

[23] Explaination of Al-Faraby to book of Arestu Talis in the Phrase, care to publish it :Welham Kutsh Al-yaswei and Stanli Maru Al-yaswei , Edition Al-Kathulikia- Beirut,1960.

[24] The Healing - The Logic - The Phrase, Ibn Sina, investigation:Dr. Mahmud Al-Kuhdary,Dar Al-Kitab Al-Arabi- Cairo,1970.

[25] Al-Sahibi book in the philology ,Ahmad Ibn Faris, investigation: Alsayd Ahmad Saqr, 1st,corporation of Al-mukhtar- Cairo,2005.

[26] Description of The Island of Arabian ,Al-Hasan Ibn Ahmad Al-Hamadany, investigation: Mohammad Ibn Ali Al-Akwaa,Dar Al-Ymama- Al-ryad,1974.

[27] Layers of The Grammarians and The Linguists ,Abu Bakr Al-Zubaydy , investigation: Muhammad Abu Al-Fadl Ibrahim , 2st,Dar Al-Maarif - Egypt , w.d.

[28] Al-Umda in Aesthetics of The Poerty and his literatures and his Criticism,Al-Hasan Ibn Rasheeq Al-Qirwany, investigation:Dr.Abd Al-Hamid Henadawy,Al-Maktaba Al-asriaBeirut, 2007.

[29] Standard of The Poerty, Ibn Tabatoba Al-Alawy, investigation:Abbas Abd Al-Satir, 2st,Dar Al-Kutub Al-IImia- Beirut,2005.

[30] Astranger of Hadith,Hamad Ibn Muhammad Al-Khattaby, investigation:Abd Al-Karim AlAzbawy,Association of Um Al-Qura،1982.

[31] Al-Fadil ,Muhammad Ibn Yazid Al-Mubarrid, investigation: Abd Al-Aziz Al-Maimny,Dar AlKutub Al-Mesria- Cairo, 1956

[32] Chapters in The Arab Jurisprudence ,Dr.Ramadan Abd Al-Tawwab , 2st, Library Al-Khanjy -Cairo, 1980 . 
[33] Councils of Thalab ,Ahmad Ibn Yahya Thalab,explination and investigation :Abd Al-Salam Muhammad Harun, 6st,Dar Al-Maref- Cairo,2006.

[34] Majma Al-Bayan in Interpretation of The Quran,Abu Ali Al-Tabrasy, investigation:Acommittee from scholars, 2st, corporation of Al-Aalamy for PublicationsBeirut, 2005.

[35] Al-Mukhasas, Ibn Sayda,Dar Al-Kutub Al-IImia- Beirut,w.d.

[ 36] The Entrance to The Linguistic and Methods of Research Linguist,Dr.Ramdan Abd AlTawwab, 3st, Library Al-Khanjy - Cairo,1997.

[37] Almuzher in Science of The Language and Their types ,Jalal Al-Diyn Al-Sywaity,set it and correct it and put his comments :Fwaad Ali Mansur, 1st,Dar Al-Kutub Al-Ilmia- Beirut,1998.

[38] Mieyar Al-IIm in Art of The Logic ,Abu Hamid Al-Ghazaly,prefaceed and commented on it and explain it :Dr.Ali Bu Melhem, 1st,Dar Al-Helala- Beirut,1993.

[39] Al-mughni in Doors of The Monotheism and The Justice ,The Judge Abd Al-Jabbar,p5,the teams un-Islamic, investigation:Mahmood Muhammad Al-Kuhdary,Al-Dar Al-Misria for authoring and translation ,w.d .

[40] Criticism of The Poetry ,Qudama Ibn Jafar, investigation:Muhammad Abd Al-Muneim Khfajy,Dar Al-Kutub Al-IImia- Beirut,w.d.

[41] Al-Hawamil and Al-Shawamil,'Abu Ali Meskawih, investigation:Said Kusrawi, 1st,Dar AlKutub Al-IImia- Beirut,2001. 